\title{
Fundusz Gospodarki Zasobem Geodezyjnym i Kartograficznym - wybrane zagadnienia
}

\author{
The State Land Surveying and Cartographic Resource \\ Management Fund - selected issues
}

\begin{abstract}
Streszczenie:
Niniejsze opracowanie dotyczy Funduszu Gospodarki Zasobem Geodezyjnym i Kartograficznym. Wskazana została konstrukcja prawna, jaką charakteryzuje się fundusz oraz jego rola w systemie finansowym państwa. Poddano również analizie wykonywane przez niego zadania, ich ewolucję i zmiany na przestrzeni lat. Opracowanie wskazuje katalog przychodów funduszu, jego kosztów oraz środków przeznaczanych na realizację zadań funduszu w oznaczonych latach na podstawie uchwał budżetowych. Ostateczna konkluzja sprowadza się do podważenia roli funkcjonowania funduszu, jak i możliwości realizowania powierzonych zadań.
\end{abstract}

Słowa kluczowe: Fundusz Gospodarki Zasobem Geodezyjnym i Kartograficznym, fundusz celowy, zmiany legislacyjne, zadania funduszu

\begin{abstract}
:
The study concerns the State Land Surveying and Cartographic Resource Management Fund and discusses the legal structure of the fund and its role in the financial system of the state. Additionally, its tasks, their evolution and changes over the years are analysed. The article presents a catalogue of the fund's revenues, expenditures and resources allocated for the implementation of the fund's tasks in the specified years under budget resolutions. The final conclusion undermines the role of the fund as well as its ability to carry out the tasks that it was entrusted to perform.

Keywords: State Land Surveying and Cartographic Resource Management Fund, special fund, legislative changes, tasks of the Fund
\end{abstract}


Karol Baranowski - Fundusz Gospodarki Zasobem Geodezyjnym...

\section{Wprowadzenie}

Fundusz Gospodarki Zasobem Geodezyjnym i Kartograficznym jest funduszem celowym w rozumieniu przepisów ustawy o finansach publicznych z dnia 27 sierpnia $2009 \mathrm{r} .^{1}$ Został powołany do wykonywania określonych zadań z zakresu gospodarowania i udostępniania zasobów geodezyjnych i kartograficznych, które znajdują się w jego posiadaniu. Zadania te dotyczą również aktualizacji zasobu oraz jego rozwoju. Udostępniane dane są co do zasady przekazywane odpłatnie.

Celem niniejszej pracy jest analiza Funduszu Gospodarki Zasobem Geodezyjnym i Kartograficznym. Uwzględnia ona zmiany, jakie zostały względem niego przeprowadzone, jak również ich wpływ na gospodarkę finansową funduszu. Ostatecznym celem jest wskazanie miejsca oraz roli funduszu w gospodarce budżetowej państwa. W opracowaniu oprócz literatury przedmiotu dotyczącej funduszy celowych i finansów publicznych użyta została ustawa tworzącą fundusz celowy, jak również inne akty prawne mające wpływ na kształt i funkcjonowanie funduszu. Do sporządzenia wykresu zostały wykorzystane ustawy budżetowe na przestrzeni lat 2006-2019 w celu ilustracji zmian, jakimi został objęty tytułowy fundusz oraz ich wpływu na gospodarkę finansową.

\section{Fundusz celowy}

Czym jest fundusz celowy? Istnieje pewna trudność w zwięzłym przytoczeniu definicji funduszu, gdyż ustawodawca nie stworzył jej wprost, a próbując to uczynić, popełniał błędy. Jeden z nich jest zawarty w ustawie o finansach publicznych z 1998 r., gdzie ustawodawca, definiując pojęcie funduszu celowego, posłużył się definicją tautologiczną zawierającą błąd logiczny w postaci wyrażenia „funduszem jest fundusz", czyli błąd idem per idem (łac. "to samo przez to samo").

\footnotetext{
1 Tekst jednolity: Dz.U. z 2019 r., poz. 869 ze zm.
} 
Ostatecznie w literaturze powstały próby zdefiniowania czy też zakwalifikowania funduszy celowych. Fundusz celowy można określić za pomocą cech, jakie powinien posiadać. Jako jedną z nich wskazuje się na wyodrębnienie poprzez przepisy ustawowe środków z ogółu środków publicznych, które są przeznaczane na finansowanie określonych zadań państwowych. Fundusze są gromadzone i wydatkowane w sposób ciągły, a uprawnionym do ich dysponowania jest określony minister lub inny organ wskazany w ustawie tworzącej dany fundusz ${ }^{2}$.

Fundusze celowe swoją historią sięgają aż 1886 r., a także później dwudziestolecia międzywojennego. W czasach komunistycznych zgodnie z obowiązującą ustawą o prawie budżetowym ${ }^{3}$ swoje funkcjonowanie rozpoczęły fundusze centralne i terenowe. Fundusze celowe mogły być tworzone na podstawie rozporządzeń wydawanych przez Radę Ministrów. Jednakże w praktyce podstawę tworzącą fundusze celowe stanowiły ustawy, a także akty niższej rangi. Kolejna regulacja o prawie budżetowym z 3 grudnia $1984 \mathrm{r}^{4}$ umożliwiła tworzenie funduszy celowych na podstawie ustaw, czy też uchwał rad narodowych. Ostatecznie od 1991 r. do dnia dzisiejszego fundusze celowe mogą być tworzone wyłącznie w drodze ustawowej, a nie jak poprzednio - aktami niższej rangi.

Regulacje dotyczące powstania i finansowania funduszy celowych zawarte są w art. 29 ustawy o finansach publicznych z dnia 27 sierpnia 2009 r. Przepis ten określa zasady tworzenia państwowych funduszy celowych, które, jak wskazano w akcie prawnym, mogą powstać wyłączenie na podstawie odrębnej ustawy. Przychody pochodzą ze środków publicznych, a koszty są ponoszone na realizację wyodrębnionych zadań. Fundusze celowe, ze względu na swoją specyfikę, różnią się od instytucji budżetowych stopniem ich specjalizacji. Korzystają one ze

\footnotetext{
2 E. Malinowska-Misiąg, [w:] W. Misiąg (red.), Ustawa o finansach publicznych, Warszawa 2015, s. 98-99.

${ }^{3}$ Dz.U. nr 45, poz. 221 ze zm.

${ }^{4}$ Dz.U. nr 56, poz. 283 ze zm.
} 
Karol Baranowski - Fundusz Gospodarki Zasobem Geodezyjnym...

środków, które służą finansowaniu konkretnych celów z nielicznych, ale bardzo dochodowych źródeł5.

Zgodnie z art. 29 ustawy o finansach publicznych państwowe fundusze celowe nie posiadają osobowości prawnej. Stanowią wyodrębniony rachunek bankowy, którym dysponuje minister wskazany w ustawie tworzącej fundusz albo inny organ wyszczególniony w ustawie. Według art. 29 ust. 5 do państwowych funduszy celowych nie zalicza się funduszy, których jedynym źródłem przychodów, z wyłączeniem odsetek od rachunku bankowego i darowizn, jest dotacja z budżetu państwa. W związku z tym w literaturze wskazuje się, że skoro fundusz nie jest w stanie sam generować przychodów, nie posiada wyszczególnionych źródeł, a co więcej jest finansowany ze środków publicznych w formie dotacji budżetowych, jego odłączenie od budżetu jest bezcelowe oraz sztuczne, a tym samym zaprzecza koncepcji tworzenia funduszy celowych jako wyodrębnionych jednostek sektora finansów publicznych6.

Następnie art. 29 ust. 6 stanowi, że podstawą gospodarki finansowej państwowego funduszu celowego jest roczny plan finansowy. Również art. 122 zawiera nakaz załączania do ustawy budżetowej planów finansowych przychodów i kosztów funduszy celowych, które są określone w planie i dotyczą realizacji zadań, co w doktrynie wskazuje się jako kolejną cechę określającą fundusze celowe. Nie jest to jednak cecha właściwa dla wszystkich funduszy celowych, w związku z czym stanowi jedynie element pomocniczy przy klasyfikacji jako fundusz celowy ${ }^{7}$. Zgodnie z art. 29 ust. 7 i 8 ze środków państwowego funduszu celowego mogą być udzielane pożyczki jednostkom samorządu terytorialnego, jeżeli akt tworzący fundusz tak stanowi. W ustawie wskazano sposób finansowania, w którym koszty państwowego funduszu celowego mogą być pokrywane tylko w ramach posiadanych środków fi-

\footnotetext{
5 B. Brzeziński, A. Olesińska (red.), Prawo finansów publicznych, Toruń 2017, s. 145.

6 E. Rutkowska-Tomaszewska, [w:] Prawo finansowe, R. Mastalski, E. Fojcik-Mastalska (red.), Warszawa 2013, s. 72-73.

7 D. Maśniak, [w:] Podstawy Finansów i Prawa Finansowego, A. Drwiłło (red.), Warszawa 2014, s. 398.
} 
nansowych obejmujących bieżące przychody, w tym dotacje z budżetu państwa i pozostałości środków z okresów poprzednich. Należy wskazać, że środki przechodzące na okres następny były znaczne, o czym świadczy Wykres III i IV.

Zgodnie z art. 29 ust. 9, 10, 11, 12 ustawy o finansach publicznych w planie finansowym państwowego funduszu celowego mogą być dokonywane zmiany polegające na zwiększeniu prognozowanych przychodów i odpowiednio zwiększeniu kosztów. Zmiany planu finansowego państwowego funduszu celowego nie mogą jednak powodować zwiększenia dotacji z budżetu państwa. Jeżeli państwowy fundusz celowy posiada zobowiązania wymagalne, w tym kredyty i pożyczki, zwiększenie przychodów w pierwszej kolejności przeznacza się na ich spłatę. Zmiany kwot przychodów i kosztów państwowego funduszu celowego, ujętych w planie finansowym, dokonuje odpowiednio minister lub organ dysponujący tym funduszem po uzyskaniu zgody ministra finansów oraz opinii sejmowej komisji do spraw budżetu.

\section{Podstawa prawna funkcjonowania FGZGiK}

Fundusz Gospodarki Zasobem Geodezyjnym i Kartograficznym został utworzony na podstawie art. 41 ustawy dnia 17 maja 1989 r. o Prawie Geodezyjnym i Kartograficznym ${ }^{8}$. Zgodnie ze wskazanym powyżej artykułem Fundusz Gospodarki Zasobami Geodezyjnymi i Kartograficznymi zwany jest dalej funduszem w rozumieniu ustawy $\mathrm{z}$ dnia 27 sierpnia 2009 r. o finansach publicznych. Przepis ten stanowi podstawę tworzącą fundusz, jednak zawiera on także bardzo istotny katalog zadań, jakich realizacją ma się on zająć. Wymieniono również źródła, z których mają być te zadania finansowane. Szerzej - prawo geodezyjne i kartograficzne stanowi fundament funkcjonowania funduszu, w którym znajdują się m.in. definicje pojęć zasobu. Jest także podstawą kompetencyjną dla innych organów, przyznającą możliwość realizacji zadań związanych z geodezją i kartografią. Ustawa ta była kilkakrotnie

\footnotetext{
8 Tekst jednolity: Dz.U. z 2019 r., poz. 725 ze zm.
} 
Karol Baranowski - Fundusz Gospodarki Zasobem Geodezyjnym...

zmieniana (o poszczególnych zmianach będzie mowa w dalszej części opracowania, z uwzględnieniem wpływu na funkcjonowanie Funduszu Gospodarki Zasobem Geodezyjnym i Kartograficznym).

\section{Zadania Funduszu}

Fundusz został utworzony w związku z potrzebą uregulowania kwestii w zakresie zasobów geodezyjnych i kartograficznych. Ustawodawca postanowił stworzyć fundusz celowy, który realizowałby zadania z zakresu geodezji i kartografii, zajmował się owymi zasobami, ich przetwarzaniem, udostępnianiem materiałów i danych podmiotom zainteresowanym, a także tworzyłby ogólnokrajową strukturę, w której zasoby te byłyby przechowywane oraz aktualizowane. Taka forma działalności pozwoliła przede wszystkim na ucieczkę przed rygorem gospodarki budżetowej, co ma związek z zasadą roczności budżetowej, gdzie środki niewykorzystane nie wygasają, a fundusz ma możliwość wykorzystywania środków w późniejszym czasie9. Ustawodawca stworzył i określił ramy, a także sposób działania funduszu, który umożliwia bardziej niezależne wykonywanie zadań wyspecjalizowanych.

Do zadań finansowanych ze środków Funduszu Gospodarki Zasobem Geodezyjnym i Kartograficznym, według art. 41 ust. 3 ustawy powołującej fundusz, należy dofinansowanie zadań związanych z aktualizacją i utrzymywaniem państwowego zasobu geodezyjnego oraz kartograficznego, a w szczególności: zakładanie, aktualizację i modernizację krajowego systemu informacji o terenie, map topograficznych i tematycznych, osnów geodezyjnych, mapy zasadniczej, geodezyjnej ewidencji sieci uzbrojenia terenu, ewidencji gruntów i budynków. Do zadań możemy zaliczyć także zakup urządzeń i wyposażenia lokali niezbędnych do prowadzenia zasobu oraz informatyzację zasobu, w tym zakup sprzętu informatycznego i oprogramowania. Do zadań wskazanych w art. 41 ust. 3 zaliczyć należy również podnoszenie kwalifikacji

\footnotetext{
${ }^{9}$ M. Tyniewicki, [w:] Nowa ustawa o finansach publicznych wraz z ustawq wprowadzająca, E. Ruśkowski, J. M. Salachn (red.), Gdańsk 2010, s. 122.
} 
pracowników Służby Geodezyjnej i Kartograficznej zatrudnionych w związku z prowadzeniem zasobu, poprzez pokrywanie kosztów szkoleń, narad i konferencji w zakresie udostępniania, aktualizacji, utrzymywania i rozwoju tego zasobu. Do zadań zaliczyć można opracowywanie, drukowanie i dystrybucję standardów oraz instrukcji technicznych, a także materiałów informacyjnych dotyczących zasobu, jak również upowszechnianie informacji o zasobie bądź działalność wydawniczą Służby Geodezyjnej i Kartograficznej. Dodany artykuł 41 ust. 3a określa, iż środki Funduszu, poza dofinansowaniem zadań, o których mowa w ust. 3, przeznacza się również na finansowanie kosztów przeprowadzania postępowania kwalifikacyjnego dla osób ubiegających się o nadanie uprawnień zawodowych $\mathrm{w}$ dziedzinie geodezji i kartografii oraz kosztów druku i dystrybucji dziennika praktyki zawodowej, finansowanie kosztów przeprowadzania testu umiejętności w postępowaniu w sprawie uznania kwalifikacji do wykonywania zawodów regulowanych w dziedzinie geodezji i kartografii.

Zakres wykonywania zadań obejmuje wyżej wymienione punkty, dotyczące szeroko rozumianej geodezji i kartografii. Materiały udostępniane przez fundusz, jak i realizowane zadania są skorelowane z działalnością Głównego Geodety Kraju, jak również Głównego Urzędu Geodezji i Kartografii działającego pod jego kierownictwem. Fundusz Gospodarki Zasobem Geodezyjnym i Kartograficznym stanowi pewną podporę funkcjonowania zasobu jako zbioru. Dzięki wyodrębnionym zadaniom fundusz ma możliwości aktualizacji informatyzacji i udostępniania owych zasobów. Te działania wspiera przede wszystkim Główny Geodeta Kraju jako dysponent środków funduszu oraz jako prowadzący centralny zasób geodezyjny.

Fundusz Gospodarki Zasobem Geodezyjnym i Kartograficznym od początku swojego istnienia ulegał wielokrotnym zmianom poprzez działania organów ustawodawczych, jak również w związku z wyrokiem Trybunału Konstytucyjnego. 
Karol Baranowski - Fundusz Gospodarki Zasobem Geodezyjnym...

W ustawie prawo geodezyjne i kartograficzne obowiązującej od dnia 24 listopada 2005 r.10 w art. 41 zawarto następujące źródła przychodu funduszu centralnego: wpływy ze sprzedaży map oraz innych materiałów i informacji z zasobu centralnego, wpływy z opłat za czynności związane z prowadzeniem tego zasobu, przekazywane w okresach kwartalnych, w ciągu 30 dni od zakończenia kwartału, wpłaty z funduszy wojewódzkich i powiatowych w wysokości 10\% ich wpływów, a także inne wpływy. Katalog ustawowy obejmował także wpłaty na fundusz centralny, które geodeta powiatowy przekazywał za pośrednictwem geodety wojewódzkiego. Czyli można zauważyć, że głównymi przychodami były wpływające opłaty z udostępniania materiałów z zasobu centralnego. Kolejnym znacznym przychodem był udział przekazywany z funduszów powiatowych i wojewódzkich do centralnego funduszu za opłaty uiszczane we właściwych funduszach terenowych. Wspomniany artykuł określał również zakres zadań, w którym środki miały być przeznaczone na uzupełnienie środków budżetowych niezbędnych do finansowania zadań związanych $\mathrm{z}$ aktualizacją oraz utrzymywaniem państwowego zasobu geodezyjnego i kartograficznego, jak i na zakup urządzeń i wyposażenie lokali niezbędnych do prowadzenia tego zasobu. Należałoby zauważyć, że wymienione przychody funduszu były bardzo dochodowe, co można zauważyć na Wykresie II.

Reforma podjęta przez ustawodawcę doprowadziła do uchwalenia ustawy o finansach publicznych. Przeprowadzono szereg działań mających poprawić oraz zapewnić efektywniejszą gospodarkę finansami publicznymi, jak to określono w projekcie tej ustawy. Uchwalono ją 27 sierpnia 2009 r. ${ }^{11}$, a część jej przepisów weszła w życie z dniem 1 stycznia 2010 r. W projekcie prawodawca przedstawił zmiany, uzasadniając ich wprowadzenie oraz opisując ich zamierzony efekt. Swoim zasięgiem objęły one nie tylko Fundusz Gospodarki Zasobem Geodezyjnym i Kartograficznym, ale także inne formy organizacyjne finansów pu-

\footnotetext{
10 Dz. U. Nr 240, poz. 2027.

11 Tekst jednolity: Dz.U. z 2017r., poz. 2077 ze zm.
} 
blicznych. Miało to na celu ograniczenie ich liczby, a także zwiększenie przejrzystości finansów publicznych ${ }^{12}$.

W opracowaniach naukowych dotyczących problematyki funduszy celowych stwierdza się, że jedną z najważniejszych przyczyn ich tworzenia jest zapewnienie ciągłości finansowania określonych zadań; pewność, że środki na określone działania będą dostępne niezależnie od sytuacji, w jakiej znajduje się bieżący budżet. Ważny jest także fakt, że zasady gospodarki finansowej, z którymi związane są fundusze celowe, są znacznie bardziej elastyczne niż zasady, które obowiązują jednostki budżetowe. Stworzenie funduszu pociąga za sobą wyodrębnienie z budżetu części dochodów, ale także wydatków. W powodach tworzenia funduszy celowych wskazuje się także przyczynę socjotechniczną, która ma na celu uwidocznienie społeczeństwu powiązania konkretnego celu, na który przeznaczone będą środki z nowych obciążeń ${ }^{13}$.

W literaturze wskazuje się szereg negatywnych aspektów związanych z funkcjonowaniem i tworzeniem funduszy, do których możemy zaliczyć, oprócz osłabionej możliwości kontroli funduszy, także wzrastające w związku z rozdrobnieniem koszty administrowania określonymi środkami. Powoduje to w konsekwencji brak efektywności wykorzystywanych środków. Podnosi się także, że nie ma możliwości realizacji zadań, do których fundusz nie został powołany. Zadania są ściśle określone i nie ma możliwości na elastyczność w ich realizacji i na ewentualne modyfikacje ${ }^{14}$. Możliwość prowadzenia nadzoru nad funduszami celowymi ogranicza się do bieżącego nadzoru właściwego ministra bądź organu uprawnionego do dysponowania środkami funduszu, w tym przypadku Głównego Geodety Kraju, którzy współpracują przy tym z ministrem właściwym do spraw finansów. Istotnym faktem

${ }^{12}$ A. Mikos-Sitek, [w:] Finanse publiczne i prawo finansowe, A. Nowak-Far (red.), Warszawa 2011, s. 258.

${ }^{13}$ E. Malinowska-Misiąg, [w:] [Komentarz do art. 29], Ustawa o finansach publicznych, W. Misiąg (red.), Komentarz, C. H. Beck, Warszawa 2019, Legalis [dostęp 01-042019].

${ }_{14}$ W. Bożek, P. Mańczyk, [w:] Ustawa o Finansach publicznych, Z. Ofiarski (red.), Warszawa 2019, s. 213. 
Karol Baranowski - Fundusz Gospodarki Zasobem Geodezyjnym...

jest, iż rozwiązanie to ciągnie za sobą ograniczenie w możliwościach kontrolnych władzy ustawodawczej, co według autora sprzyja marnotrawstwu środków publicznych ${ }^{15}$.

Wcześniejsze regulacje znajdujące się $\mathrm{w}$ ustawie o finansach publicznych z 2005 r. dotyczące funduszy celowych były bardzo lakoniczne - w ustawodawstwie brakowało spójnych i jednolitych aktów prawnych, które określałyby ramy ich funkcjonowania ${ }^{16}$. Doprowadziło to do utrudnionego przepływu środków finansowych, w związku z czym ustawodawca zauważył potrzebę zmiany.

Projektodawca zwrócił uwagę na kwestie znacznego rozproszenia gospodarki sektora finansów publicznych w postaci licznych funduszy, co powodowało skomplikowanie procesów gromadzenia, a co za tym idzie - przeznaczania środków publicznych. Owe problemy skłaniały do konkluzji, że widoczne dylematy nieprawidłowości na przestrzeni wieloletniej praktyki nie zapewniały dostatecznego poziomu celowości i racjonalności gospodarowania środkami publicznymi. Projektodawca zauważył potrzebę zmiany ilości i jakości organizacji oraz funkcjonowania funduszy celowych, dokonaną z punktu widzenia jawności, racjonalności i przejrzystości ${ }^{17}$.

Wnioskodawca postuluje zmiany w zakresie funkcjonowania funduszy celowych. Projekt przewiduje funkcjonowanie jedynie państwowych funduszy celowych powoływanych na podstawie ustawy. Ich przychody miałyby pochodzić ze środków publicznych i być przeznaczane na realizację wyodrębnionych zadań. Istotny jest fakt, że ustawa z dnia 27 sierpnia 2009 r. przepisy wprowadzające ustawę o finansach publicznych w art. 90 zlikwidowała z dniem 31 grudnia 2010 r. wojewódzkie i powiatowe fundusze gospodarki zasobem geodezyjnym i kartograficznym, tworzące wraz z funduszem centralnym Fundusz Gospodarki Zasobem Geodezyjnym i Kartograficznym.

15 D. Maśniak, [w:] Podstawy Finansów..., op. cit., s. 398.

16 B. Brzeziński, A. Olesińska (red.), Prawo finansów..., op. cit., s. 147-149.

17 Uzasadnienie projektu ustawy - Przepisy wprowadzające ustawę o finansach publicznych - Druk Nr 1181 Sejmu RP VI kadencji, s. 4. 
Projektodawca w uzasadnieniu do projektu wielokrotnie zwraca uwagę, że mimo sporych zmian, realizacja zadań funduszu nie będzie zachwiana. Nastąpi płynne przejście do nowych zmienionych realiów wynikających z reformy sektora finansów publicznych. Działania mają być przede wszystkim realizowane z zachowaniem racjonalności. Jednym z najistotniejszych aspektów było zachowanie ciągłości wykonywania zadań18. Projektodawca ma na względzie odpowiednie wykorzystanie pracowników i składników majątkowych likwidowanych podmiotów, aby zapewnić jednostkom przejmującym zadania możliwość jak najlepszej ich realizacji ${ }^{19}$.

Na mocy ustawy z dnia 27 sierpnia 2009 r. przepisy wprowadzające ustawę o finansach publicznych ${ }^{20}$ dokonano zmian w niżej wymienionych przepisach zawartych w ustawie o prawie geodezyjnym i kartograficznym: art. 7a pkt 3 , art. 7c pkt 1 , art. 7 d pkt 1 , art. 41 ; uchylono art. 41a, dodano art. 41b.

W wyżej wymienionym artykule 7a pkt 3 zmieniona została nazwa z Centralnego Funduszu Gospodarki Zasobem Geodezyjnym i Kartograficznym na Fundusz Gospodarki Zasobem Geodezyjnym i Kartograficznym -usunięto słowo „Centralnego”. Główny Geodeta Kraju, jak wskazuje przepis, prowadzi centralny zasób geodezyjny i kartograficzny oraz dysponuje środkami Funduszu Gospodarki Zasobem Geodezyjnym i Kartograficznym.

Na podstawie art. 41b ust. 1, 2 i 3 ustawy Prawo Geodezyjne i Kartograficzne wpływy, jakie wygenerowały dotychczas wojewódzkie i powiatowe fundusze, stają się od dnia 1 stycznia 2011 r. dochodami własnymi budżetu samorządu wojewódzkiego i powiatowego oraz mają być nadal wykorzystane na cele związane z zakresem geodezji i kartografii na podstawie art. $41 \mathrm{~b}$ ust. 3. Zakres realizowanych zadań został przeniesiony wraz z przychodami na samorządy - to na nich oparto

\footnotetext{
18 W. Bożek, P. Mańczyk, [w:] Ustawa o Finansach..., op. cit., s. 214.

19 Uzasadnienie projektu ustawy - Przepisy wprowadzające ustawę o finansach publicznych - Druk Nr 1182 Sejmu RP VI kadencji, s. 8.

20 Dz.U. Nr 157, poz. 1241, ze zm.
} 
Karol Baranowski - Fundusz Gospodarki Zasobem Geodezyjnym...

zdecydowany ciężar realizacji zadań z zakresu obsługi zasobów geodezyjnych i kartograficznych. Dokonano również zmiany w art. 7c pkt 1, gdzie zakres zadań marszałka województwa obejmował w szczególności prowadzenie wojewódzkiego zasobu geodezyjnego i kartograficznego.

Została usunięta część dotycząca dysponowaniem środkami wojewódzkiego Funduszu Gospodarki Zasobem Geodezyjnym i Kartograficznym, który przestał istnieć. Doszło także do zmiany w zakresie zadań starosty wymienionych $\mathrm{w}$ art. $7 \mathrm{~d}$ pkt 1 . Należy do niego w szczególności prowadzenie powiatowego zasobu geodezyjnego i kartograficznego. Zostało również usunięte sformułowanie dotyczące powiatowego funduszu (który przestał istnieć), a wpływy zaczęły zasilać odpowiednio wojewódzkie i powiatowe budżety samorządowe. Fundusz Gospodarki Zasobem Geodezyjnym i Kartograficznym został także pozbawiony, po zmianie w art. 41 ust. 2, dochodów z wpłat z funduszów wojewódzkich i powiatowych w wysokości $10 \%$ ich wpływów przekazywanych na fundusz centralny. W wyniku działań legislacyjnych został również uchylony art. 41a. W przypadku przejęcia kompetencji przez wójtów (burmistrzów, prezydentów miast), zgodnie z art. 6a ust. 4, tworzy się gminny Fundusz Gospodarki Zasobem Geodezyjnym i Kartograficznym, gdyż z uwagi na zmiany funkcjonowanie gminnych funduszy, nawet dla zadań określonych $\mathrm{w}$ art. 6a, byłoby bezcelowe.

Przedstawione zmiany przeniosły ciężar związany z gospodarką zasobem geodezyjnym i kartograficznym z wcześniej istniejących funduszy wojewódzkich, powiatowych oraz centralnego na samorządy. Według uzasadnienia do wydania ustawy o przepisach wprowadzających ustawę o finansach publicznych zmiany skutkować miały likwidacją samorządowych funduszy celowych. Nie miały one na celu pozbawienia samorządów środków przeznaczanych na zadania z zakresu gospo- 
darki zasobem geodezyjnym i kartograficznym, a jedynie uproszczenie ich przepływu ${ }^{21}$.

W znowelizowanej ustawie tworzącej fundusz, z uwagi na zmiany związane z wprowadzeniem przepisów wprowadzających ustawę o finansach publicznych, katalog przychodów na dzień wejścia w życie 1 stycznia 2011 r. zawierał na podstawie art. 41 ust. 222: wpływy ze sprzedaży map oraz innych materiałów i informacji z zasobu centralnego, wpływy z opłat za czynności związane z prowadzeniem tego zasobu, przekazywane w okresach kwartalnych, w ciągu 30 dni od zakończenia kwartału, a także inne wpływy. Istotnym jest, że wyżej opisane zmiany legislacyjne miały znaczący wpływ na gospodarkę finansową funduszu, gdyż na ich kanwie utraciła ona źródła przychodów o znacznych wartościach, co można zaobserwować w szczególności na podstawie Wykresu II.

Przedstawione zmiany nie były ostateczne. W późniejszym czasie ustawodawca poszerzył katalog dochodów. Nowelizacja ustawy o prawie geodezyjnym i kartograficznym z 23 sierpnia 2013 r. ${ }^{23}$ określała, że przychodami Funduszu zawartymi w art. 41 ust. 2 były wpływy z opłat za udostępnienie zbiorów danych oraz innych materiałów z zasobu centralnego oraz za czynności urzędowe związane z prowadzeniem tego zasobu. Również wpływy za przeprowadzenie postępowania kwalifikacyjnego dla osób ubiegających się o nadanie uprawnień zawodowych w dziedzinie geodezji i kartografii oraz za wydanie dziennika praktyki zawodowej. Także za przeprowadzenie testu umiejętności w postępowaniu w sprawie uznania kwalifikacji do wykonywania zawodów regulowanych w dziedzinie geodezji i kartografii.

Dokonane zmiany były spowodowane realizacją zapowiedzi zmian legislacyjnych, początkowo wskazanych w exposé premiera Donalda Tuska. Zobowiązano się w nim do podjęcia działań rządowych w celu

\footnotetext{
${ }^{21}$ Uzasadnienie projektu ustawy - Przepisy wprowadzające ustawę o finansach publicznych - Druk Nr 1182 Sejmu RP VI kadencji, s. 5.

22 Tekst jednolity: Dz.U. z 2010 r., nr 193, poz. 1287 ze zm.

23 Dz.U. z 2013 r., poz. 829 ze zm.
} 
Karol Baranowski - Fundusz Gospodarki Zasobem Geodezyjnym...

zmniejszenia liczby zawodów regulowanych w Polsce, jak i urzeczywistnienia wartości konstytucyjnych, w szczególności zawartych w art. 31 Konstytucji RP. ${ }^{24} \mathrm{Z}$ uwagi na ten postulat dokonano zmian legislacyjnych, gdzie projektodawca w uzasadnieniu do ustawy stwierdza, iż:

(...) zachodzi wobec powyższego konieczność uporządkowania docelowego stanu regulacji zasad podejmowania i wykonywania określonej grupy zawodów, tak aby zarówno ograniczenia były oparte o istotne i czytelne kryteria, jak również, by między regulacjami dotyczącymi podobnych grup zawodowych nie zachodziły istotne, pozbawione podstawy merytorycznej różnice ${ }^{25}$.

Ustawodawca stwierdził, że istnieje potrzeba uregulowania grupy zawodów, do której udział administracji publicznej w procesie uzyskiwania uprawnień do wykonywania zawodu jest konieczny. Pozwala to na pewien wpływ organów zarówno na liczbę, jak i poziom kwalifikacji osób, które miałyby wykonywać określone zawody, w tym zawód geodety $^{26}$.

W przychodach w ustawie tworzącej fundusz dodany został do aktu prawnego art. 41 ust. 2 pkt 4 wprowadzony 12 lipca 2014 r.27 Zmiana ta dodała kolejne źródło dochodu funduszu, którym są wpływy z opłat za udostępnianie materiałów należących do centralnego zasobu geodezyjnego i kartograficznego przez marszałków województw i starostów na zasadach określonych w art. 40h lub art. 40i.

Fundusz realizuje także ustawowo określone zadania, które na przestrzeni lat również były zmieniane - dwukrotnie. W pierwotnym brzmieniu ustawy prawo geodezyjne i kartograficzne ${ }^{28}$ do zadań funduszu należało uzupełnienie środków budżetowych niezbędnych do finansowania zadań związanych z aktualizacją i utrzymywaniem pań-

${ }^{24}$ Konstytucja Rzeczypospolitej Polskiej z dnia 2 kwietnia 1997r. (Dz.U. z 1997 r., nr 78, poz. 483 ze zm.).

${ }^{25}$ Uzasadnienie projektu ustawy o zmianie ustaw regulujących wykonywanie niektórych zawodów - Druk Nr 806 Sejmu RP VI kadencji, s. 2.

26 Uzasadnienie projektu ustawy o zmianie ustaw regulujących wykonywanie niektórych zawodów - Druk Nr 806 Sejmu RP VI kadencji, s. 4-6.

27 Dz.U. z 2014 r., poz. 897 ze zm.

${ }^{28}$ Dz.U. 1989, nr 30, poz. 163. 
stwowego zasobu geodezyjnego i kartograficznego oraz zakupu urządzeń niezbędnych do prowadzenia tego zasobu.

Pierwsza ze zmian miała miejsce wraz ze szczegółowo opisaną już zmianą ustawy o finansach publicznych ${ }^{29}$. Fundusz na podstawie wyżej wymienionego aktu prawnego ze swoich przychodów miał przeznaczać środki na dofinansowanie zadań związanych z aktualizacją i utrzymywaniem państwowego zasobu geodezyjnego i kartograficznego, w szczególności na zakładanie, aktualizację i modernizację krajowego systemu informacji o terenie, map topograficznych i tematycznych, osnów geodezyjnych, mapy zasadniczej, geodezyjnej ewidencji sieci uzbrojenia terenu, ewidencji gruntów i budynków. Jak wskazuje ustawa, również środki wykorzystywane na zakup urządzeń i wyposażenia lokali niezbędnych do prowadzenia zasobu. W dobie cyfryzacji do tego ustawowego katalogu dodano informatyzację zasobu, w tym zakup sprzętu informatycznego i oprogramowania oraz podnoszenie kwalifikacji pracowników Służby Geodezyjnej i Kartograficznej zatrudnionych w związku z prowadzeniem zasobu poprzez pokrywanie kosztów szkoleń, narad i konferencji w zakresie udostępniania, aktualizacji, utrzymywania i rozwoju tego zasobu. Ponadto do zadań dodano opracowywanie, drukowanie i dystrybucję standardów oraz instrukcji technicznych, a także materiałów informacyjnych dotyczących zasobu oraz upowszechnianie informacji o zasobie, jak i działalność wydawniczą Służby Geodezyjnej i Kartograficznej. Dokonane zmiany pozostawiły dość wyspecjalizowane kompetencje funduszu, natomiast pozbawiono go środków na ich tak obszerną realizację, jak w latach przed 2010 r., co można zauważyć na podstawie Wykresu I.

Do wyżej wymienionego już katalogu w 2013 roku w związku z wejściem w życie ustawy o zmianie ustaw regulujących wykonywanie niektórych zawodów z dnia 13 czerwca 2013 r. ${ }^{30}$ dodano, iż w akcie prawnym tworzącym fundusz $\mathrm{w}$ art. 41 ust. 3 zadaniem, na które miały

29 Ustawa z dnia 27 sierpnia 2009 r. Przepisy wprowadzające ustawę o finansach publicznych, Dz.U. z 2009 r., nr 157, poz. 1241 ze zm.

30 Dz.U. z 2013 r., poz. 829 ze zm. 
Karol Baranowski - Fundusz Gospodarki Zasobem Geodezyjnym...

być przeznaczane środki będzie również finansowanie kosztów przeprowadzania postępowania kwalifikacyjnego dla osób ubiegających się o nadanie uprawnień zawodowych w dziedzinie geodezji i kartografii oraz kosztów druku i dystrybucji dziennika praktyki zawodowej. Także finansowanie kosztów przeprowadzania testu umiejętności w postępowaniu w sprawie uznania kwalifikacji do wykonywania zawodów regulowanych w dziedzinie geodezji i kartografii.

\section{Przychody funduszu}

Aktualnie po wszystkich wyżej opisanych i wymienionych zmianach legislacyjnych do katalogu środków, z których fundusz czerpie środki finansowe na podstawie art. 41 ust. 2 ustawy o Prawie Geodezyjnym i Kartograficznym, zaliczyć można m.in. wpływy z opłat za udostępnienie zbiorów danych oraz innych materiałów z zasobu centralnego oraz za czynności urzędowe związane z prowadzeniem tego zasobu. Do ustawowego katalogu zaliczyć można również przeprowadzenie postępowania kwalifikacyjnego dla osób ubiegających się o nadanie uprawnień zawodowych w dziedzinie geodezji i kartografii oraz za wydanie dziennika praktyki zawodowej. Przychodami funduszu są także wpływy $\mathrm{z}$ opłat za przeprowadzenie testu umiejętności w postępowaniu w sprawie uznania kwalifikacji do wykonywania zawodów regulowanych w dziedzinie geodezji i kartografii, jak i wpływy za udostępnianie materiałów należących do centralnego zasobu geodezyjnego i kartograficznego przez marszałków województw i starostów na zasadach określonych $\mathrm{w}$ art. 40h lub art. 40i ustawy.

Część z wymienionych przychodów, wskazanych przez ustawodawcę $\mathrm{w}$ ustawie, stanowią opłaty związane z prowadzeniem oraz udostępnianiem państwowego zasobu geodezyjnego i kartograficznego. Według art. 2 pkt 10 stanowi on zbiory danych prowadzonych na podstawie ustawy przez organy Służby Geodezyjnej i Kartograficznej, utworzone na podstawie tych zbiorów danych opracowania kartograficzne, rejestry, wykazy i zestawienia, dokumentację zawierającą wyniki prac geodezyjnych lub prac kartograficznych lub dokumenty utwo- 
rzone w wyniku tych prac, a także zobrazowania lotnicze i satelitarne. Zakres opłat zasobu centralnego reguluje art. 40 ustawy o prawie geodezyjnym i kartograficznym, zasilają one finansowo fundusz. Ustawodawca w art. 40 określił kwestie dotyczące organizacji państwowego zasobu geodezyjnego i kartograficznego oraz cele, jakim zasób ten ma służyć. Zaliczyć do nich można obronność państwa, ochronę bezpieczeństwa, naukę, kulturę i inne. Ponadto wskazano kwestie związane z przekazywaniem danych oraz materiałów innym organom Służby Geodezyjnej i Kartograficznej. Przepis ten wskazuje także właściwe organy do weryfikacji opracowań przyjmowanych do zasobu. Wskazuje także część zadań wykonywanych przez Głównego Geodetę Kraju, jak również inne organy w zakresie utrzymywania i aktualizacji czy też szerzej - całokształtu funkcjonowania zasobu ${ }^{31}$.

\section{Koszty funduszu}

Koszty ponoszone przez Fundusz Gospodarki Zasobem Geodezyjnym i Kartograficznym, uwzględnione w ustawach budżetowych, obejmują w swoim zakresie środki na realizację zadań, na które składają się m.in. wynagrodzenia pracowników, zakup usług oraz koszty inwestycyjne.Z uwagi na obszerność poszczególnych wydatków w poprzednich latach budżetowych można podzielić je, dla lepszej systematyzacji, na wydatki związane z utrzymaniem, aktualizacją, informatyzacją i zabezpieczeniem zasobu oraz $\mathrm{z}$ nadawaniem uprawnień zawodowych w dziedzinie geodezji i kartografii.

Katalog wyżej wymienionych kosztów został określony w ustawach budżetowych w latach 2016-2019. W 2014-2015 roku katalog wykorzystywanych środków został rozszerzony o zakupy związane z potrzebą informatyzacji zasobów, w tym zakup sprzętu i oprogramowania. Rozszerzono także katalog kosztów o opracowywanie i drukowa-

31 W. Potrapeluk, [w:] [Komentarz do art. 40], T. Myśliński (red.), Prawo geodezyjne i kartograficzne, Komentarz, Wolters Kluwer Polska S.A., Warszawa 2018, stan prawny na 1 lutego 2018, LEX [dostęp: 14-06-2019]. 
Karol Baranowski - Fundusz Gospodarki Zasobem Geodezyjnym...

nie oraz dystrybucję standardów i instrukcji technicznych, a także materiałów informacyjnych dotyczących zasobu, mających zwiększyć oraz upowszechnić informacje o tymże zasobie. W ramach wykonywanych zadań część środków została wykorzystana na podnoszenie kwalifikacji pracowników Służby Geodezyjnej i Kartograficznej związanej z prowadzeniem zasobu.

Jak można zauważyć, środki wykorzystywane przez fundusz od kilku lat są przeznaczane na wyżej wymienione zadania. Istotnym jest wskazanie, że nie zawsze w planie finansowania jest konieczne, by co roku przeznaczać pulę środków na jakiś określony cel, gdyż został on zrealizowany w latach ubiegłych - można tutaj wskazać jako przykład przebudowę systemu informatycznego, zakup komputerów czy sprzętu pomiarowego. Są to inwestycje, których nie trzeba wykonywać corocznie. Można powiedzieć, że w planach finansowych zawiera się zadania bieżące oraz stałe, a także pewne doraźne potrzeby w celu najefektywniejszej realizacji powierzonych zadań. Niemniej jednak widać również wpływ ustawodawstwa, np. w zakresie nadawania uprawnień zawodowych z dziedziny geodezji i kartografii, które to zadanie dodano w 2014 r. W wcześniejszych latach koszty były wielokrotnie wyższe z uwagi na rozłożenie ciężaru gospodarowania zasobu, także kilkakrotnie wyższe były dochody. Wszystko to wynikało ze zmian legislacyjnych zastosowanych przez ustawodawcę, a także ze zmian w zakresie realizacji gospodarki finansowej, co w ostateczności wpłynęło na zmianę pozycji funduszu.

Przedstawione tu zostały najważniejsze zmiany w przychodach i zadaniach mające istotny wpływ na gospodarowanie środkami zasobu. W zdecydowany sposób wpłynęły one ostatecznie na możliwości finansowe Funduszu Gospodarki Zasobem Geodezyjnym i Kartograficznym. Zmiany i zróżnicowanie w funkcjonowaniu funduszu można dostrzec, porównując coroczne plany finansowe zawarte w ustawach budżetowych.

W Wykresach I-IV doskonale można zauważyć lata, w których dokonywane były zmiany. Przede wszystkim w przedziale 2006-2010 przychody funduszu są wyższe niż w latach 2011-2019, gdyż oscylują 
w granicach od 20 do 28 mln zł. Wynikało to ze źródeł przychodu, jakie posiadał fundusz. Zaliczyć do nich możemy przede wszystkim przelewy redystrybucyjne pochodzące z powiatowych i wojewódzkich funduszy na rzecz funduszu centralnego - wynosiły one bowiem $10 \%$. Odpisy te stanowiły w latach objętych analizą ok. 90\% całego przychodu. Reszta pochodziła z wpływów z usług i sprzedaży wyrobów. Ustawodawca, przeprowadzając reformę ustawy o finansach publicznych w 2009 roku, stanął przed wyzwaniem, by mimo zlikwidowania powiatowych i samorządowych funduszy zapewnić odpowiednie dochody potrzebne do realizacji zadań. Jak już wyżej zostało przedstawione, katalog dochodów był dość ubogi. Widać to także po przychodach, jakie zawarte zostały w ustawie finansowej w latach 2011-2013. Nieznaczny wpływ na przychody miała również zmiana ustawy dotyczącej regulacji wykonywania niektórych zawodów z 2013 r., w której przeprowadzono wspomnianą reformę przychodów oraz dodano ust. 3a. Analizując wpływające do funduszu środki, trudno zauważyć większą zmianę w tym zakresie, gdyż owa reforma nie miała tego na celu.

Zmiany w 2014 r. miały polegać na poprawie gospodarki finansowej - planowano zwiększyć przychody. Jak szacowano przy przyjęciu projektu, Fundusz Gospodarki Zasobem Geodezyjnym i Kartograficznym miał osiągnąć dodatkowe wpływy, które po zmianach miały wynieść ok. $3 \mathrm{mln}$ zł, a średnioroczne wpływy miały wynosić ok. $5 \mathrm{mln}$ zł, zamiast jak w ostatnich latach 2,2 mln $\mathrm{zł}^{32}$. Do tego miało doprowadzić dodanie pkt 4 do ust. 2 art. 41 prawo geodezyjne i kartograficzne. Jednakże w tabelach dołączanych do ustawy budżetowej można zauważyć, że w ostatnich 4 latach ilość środków na wykonywanie zadań jest raczej stagnacyjna i nie ulega zmianom, tak samo jak kwoty przeznaczane na ich realizację. Można to zauważyć, analizując Wykres I.

32 Uzasadnienie projektu ustawy o zmianie ustawy - Prawo geodezyjne i kartograficzne - Druk Nr 2364 Sejmu RP VI kadencji, s. 26. 
Karol Baranowski - Fundusz Gospodarki Zasobem Geodezyjnym...

\section{Podsumowanie}

Przedstawiony Fundusz Gospodarki Zasobem Geodezyjnym i Kartograficznym funkcjonuje już od wielu lat. Po długiej analizie zmian, zakresów zadań oraz przychodów nasuwa się konkluzja, że fundusz w dzisiejszym wydaniu nie stanowi najistotniejszego elementu gospodarki finansowej państwa. Jego istnienie w obecnych realiach oraz po wymienionych zmianach jest bezcelowe. Jego funkcjonowanie i finansowanie w latach przed zmianami z 2010 roku miało jeszcze jakiś cel ze względu na czerpanie z funduszy wojewódzkich i powiatowych, wspólne wykonywanie zadań na szczeblu terenowym i krajowym oraz wspólne uczestniczenie w kosztach i przychodach. Większe środki umożliwiały realizację wielu zadań i stanowiły podstawę funkcjonowania Funduszu Gospodarki Zasobem Geodezyjnym i Kartograficznym. Jednak ze względu na rozdrobnienie i zmianę sposobu realizacji gospodarki budżetowej, a także funkcjonowania funduszy, jego rola zmalała. Z uwagi na oddanie zadań i przychodów wynikających ze zlikwidowanej działalności funduszy wojewódzkich i powiatowych samorządom, Fundusz Gospodarki Zasobem Geodezyjnym i Kartograficznym stracił na znaczeniu, jego istnienie przestało mieć sens. Realizacja zadań nie ucierpiała, co najwyżej zmienił się podmiot, który w większości miał je wykonywać oraz zawęził się krąg przepływu środków. Dziesięć lat po wprowadzonych zmianach można stwierdzić, że zamysł ustawodawcy w pewnym zakresie się ziścił, nastąpiło bowiem płynne przejście wykonywanych zadań między podmiotami. Nie zaistniała sytuacja, w której w jakikolwiek sposób doszłoby do zachwiania możliwości realizacji powierzonych zadań przez wskazane podmioty. Późniejsze podjęte działania również doprowadziły do zmian w dochodach funduszu. Jednakże należy zauważyć pewną prawidłowość, jak wskazuje Wykres III i IV. Fundusz posiadał spore oszczędności, można byłoby zastanowić się także nad względami celowościowymi funkcjonowania funduszu, którego dochody są tak duże, a mimo to nie są w całości przeznaczane na realizację zadań. 
Jak można wywnioskować z Wykresu II, po zmianach ustawodawczych dochody były niewielkie, a co za tym idzie - niewielka możliwość realizacji zadań. Warto zwrócić uwagę, że po tych znaczących reorganizacjach podstawowe funkcjonowanie zapewniły funduszowi jego oszczędności, które ze względu na swój charakter przechodzą z roku na rok, co umożliwiło mu funkcjonowanie. Jednak nie sposób nie zauważyć, że funkcjonowanie funduszu na podstawie znacznych oszczędności nie daje pewności, czy w późniejszych latach znajdą się środki na realizację zadań związanych $\mathrm{z}$ jego funkcjonowaniem. Fundusz na dzień dzisiejszy nie posiada wystarczających przychodów. Biorąc pod uwagę względy celowościowe i racjonalność, można byłoby pokusić się o stwierdzenie, że fundusz od paru lat, oprócz informatyzacji aktualizacji i utrzymywania państwowego zasobu geodezyjnego i kartograficznego oraz nadawania uprawnień zawodowych w dziedzinie geodezji i kartografii nie spełnia żadnych innych celów. Tym samym staje się niepotrzebny, a jego zadania mogłyby zostać przekazane innej samorządowej bądź państwowej instytucji, co wydawałoby się racjonalne, a także dawałoby większe gwarancje wykonywania zawartych w aktach prawnych zadań i obowiązków. 
Karol Baranowski - Fundusz Gospodarki Zasobem Geodezyjnym...

\section{Wykresy do tekstu głównego}

Finanse Funduszu Gospodarki Zasobem Geodezyjnym i Kartograficznym w latach 2006-2019

Wykres I. Kwota zaplanowana na zadania wynikające z ustawy tworzącej fundusz celowy (w tys.)

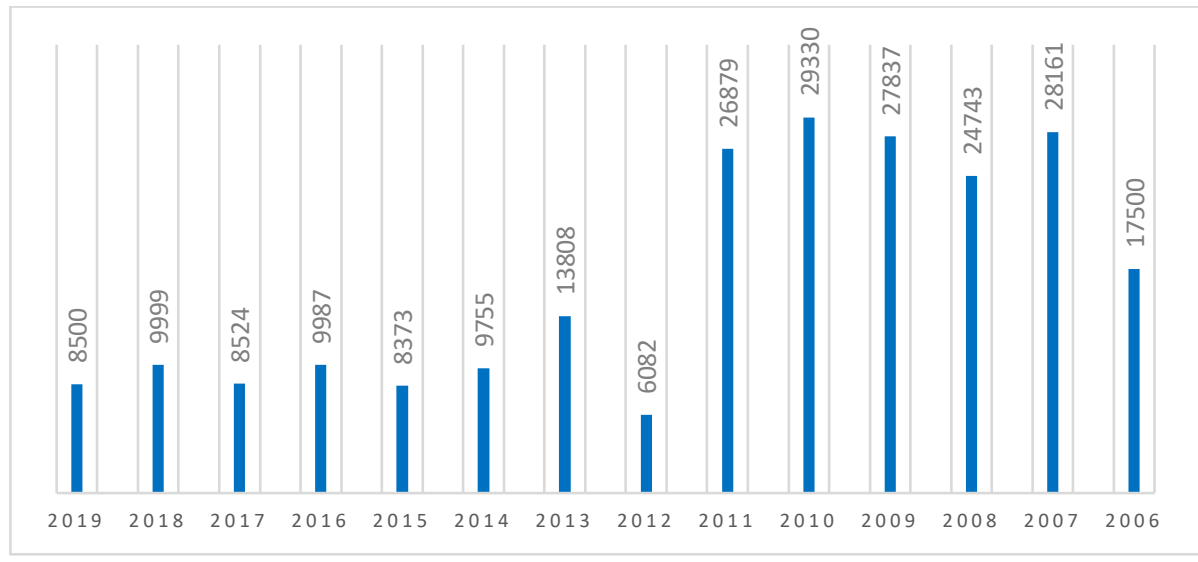

Wykres II. Przychody (w tys.)

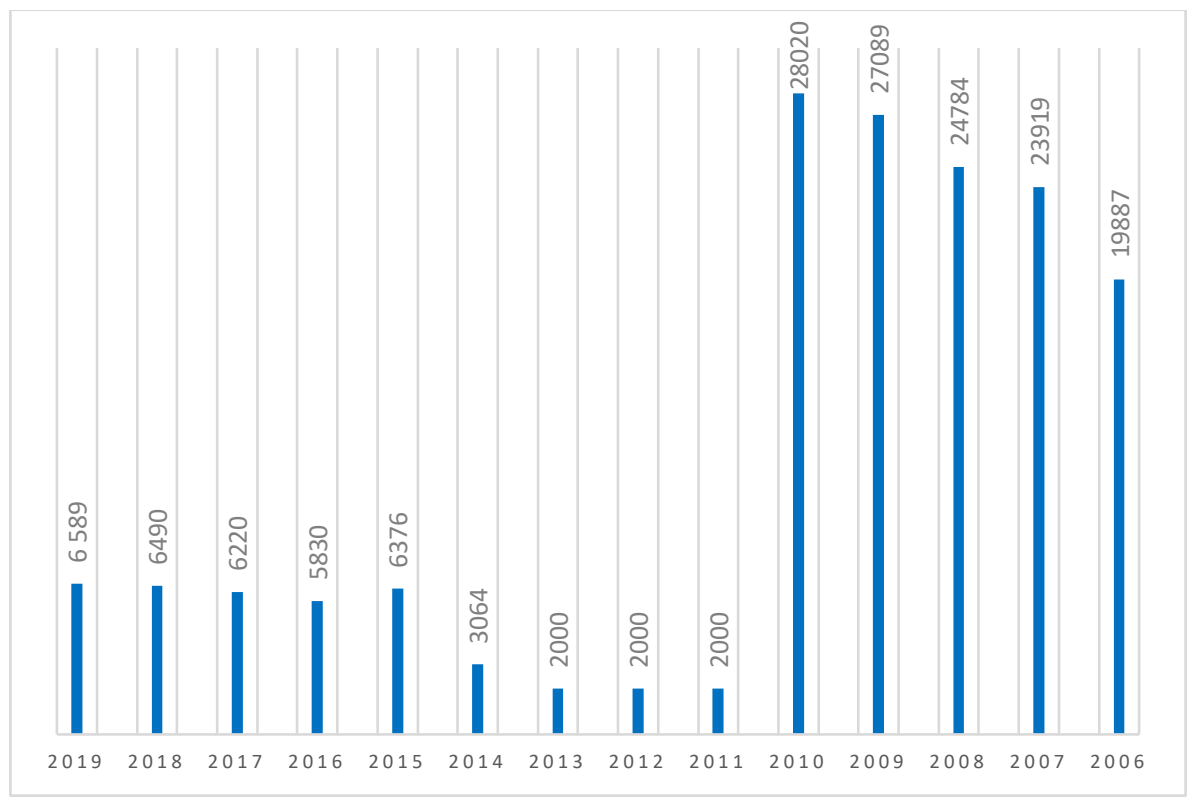


Wykres III. Stan funduszu na początek roku (w tys.)

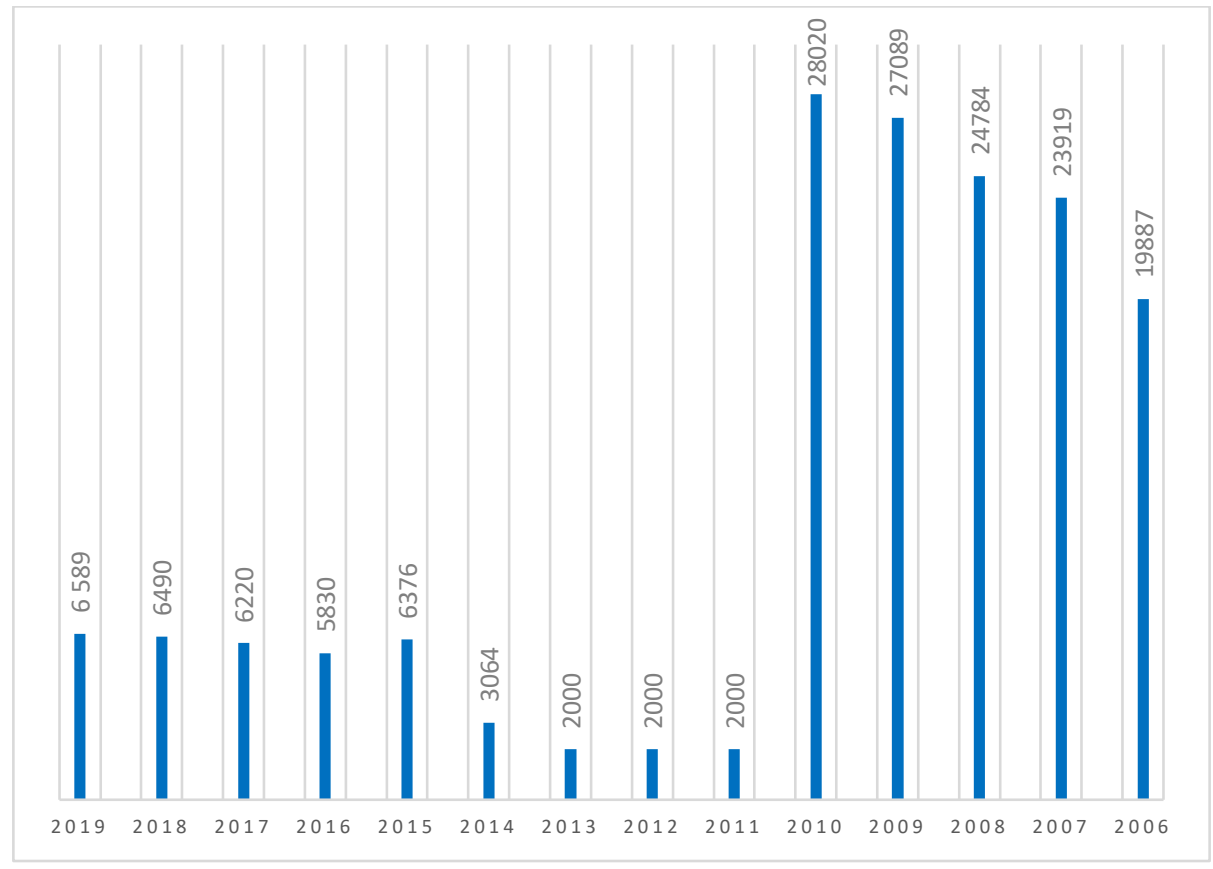

Wykres IV. Stan funduszu na koniec roku (w tys.)

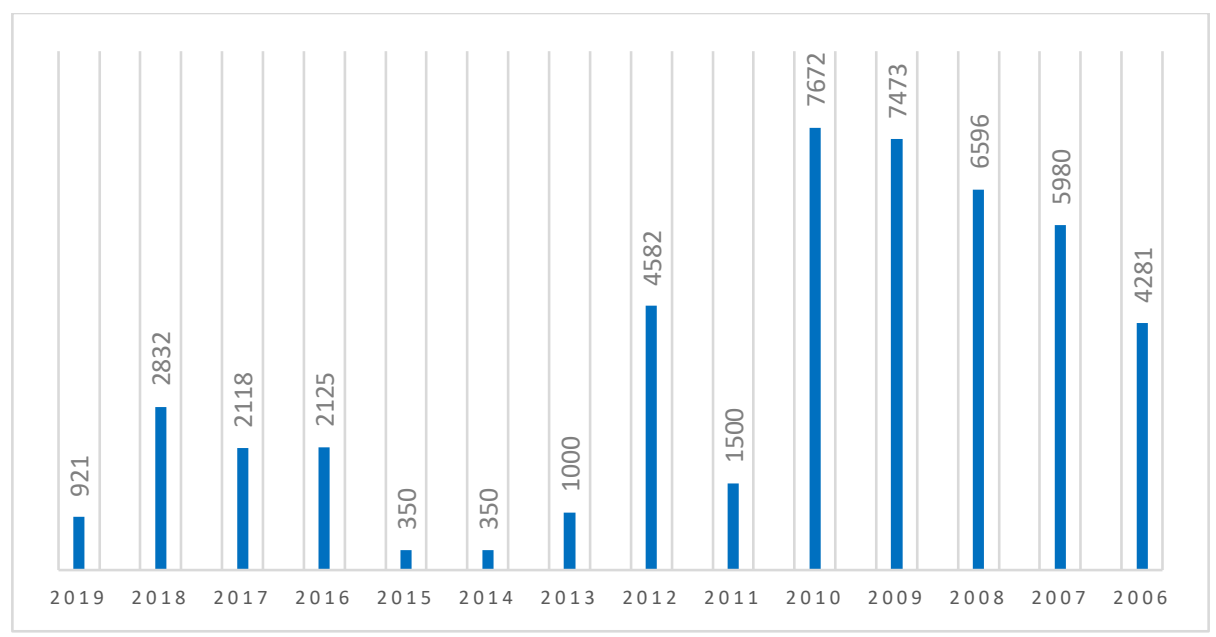

Źródło: Opracowanie własne na podstawie uchwał budżetowych z lat 2006-2019. 
Karol Baranowski - Fundusz Gospodarki Zasobem Geodezyjnym...

\section{Bibliografia:}

Bożek W., Mańczyk P., [w:] Z. Ofiarski (red.), Ustawa o finansach publicznych, Wyd. Wolters Kluwer, Warszawa 2019.

Brzeziński B., Olesińska A. (red.), Prawo finansów publicznych, Wyd. TNOiK, Toruń 2017.

Malinowska-Misiąg E., [w:] W. Misiąg (red.), Ustawa o finansach publicznych, Wyd. C.H. Beck, Warszawa 2015.

Malinowska-Misiąg E., [w:] W. Misiąg (red.), Ustawa o finansach publicznych, Komentarz, Wyd.C. H. Beck, Wydanie 3, 2019, Legalis [dostęp: 01-04-2019]. Maśniak D., [w:] A. Drwiłło (red.), Podstawy Finansów i Prawa Finansowego, Wyd. Wolters Kluwer, Warszawa 2014.

Mikos-Sitek A., [w:] A. Nowak-Far (red.), Finanse publiczne i prawo finansowe, Wyd. C.H. Beck, Warszawa 2011.

Potrapeluk W., [w:] T. Myśliński (red.), Prawo geodezyjne i kartograficzne. Komentarz, Wyd. Wolters Kluwer, Warszawa 2018, stan prawny na 1 lutego 2018, LEX [dostęp 01.04.2019].

Rutkowska-Tomaszewska E., [w:] R. Mastalski, E. Fojcik-Mastalska (red.), Prawo finansowe, Wyd. Warszawa 2013.

Tyniewicki M., [w:] E. Ruśkowski, J. M. Salachn (red.), Nowa ustawa o finansach publicznych wraz z ustawq wprowadzająca, Wyd. ODDK, Gdańsk 2010.

Konstytucja Rzeczypospolitej Polskiej z dnia 2 kwietnia 1997 r. (Dz.U. z 1997 r., nr 78, poz. 483 ze zm.).

Ustawa z dnia 17 maja 1989 r. Prawo geodezyjne i kartograficzne (Dz.U. z 1989 r., nr 30, poz. 163 ze zm.).

Ustawa z dnia 27 sierpnia 2009 r. Przepisy wprowadzające ustawę o finansach publicznych (Dz.U. z 2009 r., nr 157, poz. 1241 ze zm.).

Ustawa z dnia 27 sierpnia 2009 r. o finansach publicznych (Dz.U. z 2009 r., nr 157, poz. 1240 ze zm.).

Uzasadnienie projektu ustawy o zmianie ustawy - Prawo geodezyjne i kartograficzne - Druk nr 2364 Sejmu RP VI kadencji.

Uzasadnienie projektu ustawy - Przepisy wprowadzające ustawę o finansach publicznych - Druk nr 1182 Sejmu RP VI kadencji.

Uzasadnienie projektu ustawy o zmianie ustaw regulujących wykonywanie niektórych zawodów - Druk nr 806 Sejmu RP VI kadencji. 